\title{
Influence of Packaging Type on the Dynamics of Powdered Eggs Chemical Composition
}

\author{
ALEXANDRU USTUROI, CRISTINA SIMEANU, MARIUS GIORGI USTUROI, MARIUS GHEORGHE DOLIS, \\ ROXANA NICOLETA RATU, DANIEL SIMEANU* \\ University of Agricultural Sciences and Veterinary Medicine of lasi, 3 Mihail Sadoveanu Alley, 700490, Iasi, Romania
}

\begin{abstract}
The aim of the study was to investigate the dynamics of the main chemical compounds in the powdered eggs stored under constant environmental conditions (temperature $=10 \pm 0.5^{\circ} \mathrm{C}$; relative humidity $=65 \pm 1 \%$ ) and packaged in bags made of different plastic fabric ( Lc group = high density polyethylene - HDPE; Lexp group = low density polyethylene - LDPE). The assessments were run to measure the inner water and dry matter contents, as well as the ash, proteins, lipids and nitrogen free extract levels. The analysis of data gathered throughout 90 days of storage suggested that the product packaged in low density polyethylene bags - LDPE (Lexp group) absorbed $+0.82 \%$ humidity from the environment, compared to Lc group (highly significant differences), lost $0.41 \%$ from its initial proteins level and $0.59 \%$ of the nitrogen free extract, while lipids and ash values were not affected by the experimental factor (different package). Consequently, it might be concluded that the type and quality of the utilised package could significantly influence the proximate chemical composition, due to the transfers from the outer storage environment toward the inner volume of the package, whose intensity is given by the direct influence of the barrier features of the fabric the packages are made of.
\end{abstract}

Keywords: powder eggs, package, storage, chemical composition

Egg production industry must solve, among many issues, the one created by the increased amount of eggs pumped into market by the laying hens farmers. Sometimes, the momentary or temporary demand for this commodity (table eggs) is quite low, due to some seasonal particularities (religious fasting periods, decrease of energy concentrated food during summer and so on) $[1,2]$.

In order to be able to capitalize the available eggs on the market, the food industryadapted since the very beginning of the '70s and started to transform the exceeding amounts into egg products. Such foods mainly preserve the nutritional qualities of the raw eggs and also have longer shelf life and better stability $[3,4]$.

Thesenew food products are in accordance with the actual preferences of the consumers and especially with the increasing demand of certain food industry sectors which use eggs as main or auxiliary ingredients [5].

Despite the fact that the raw matter used in manufacturing eggs derived products is suspected to have a certain level of microbial contamination, this is significantly decreased through appropriate temperature treatment on the production flow $[6,7]$.

Pasteurizing applied on raw matter could directly influence the technological properties of the final products to be used in certain branches of the food industry $[8,9]$.

Generally speaking, egg white pasteurization is made at higher temperature levels, compared to the yolk pasteurization, whose proteins are more thermosensitive [10, 11].

One of the most appreciated eggs derived products is the powdered eggs (whole, made of white or of yolk), due to the extended shelf life, to the facility in usage/storage and to the high diversity of usage possibilities [12, 13].

Initial quality of the powdered eggs relies upon the quality of the eggs used as raw matter, the main traits being represented by eggs freshness, chemical composition, ratio between egg compartments and so on [14].
The method used in drying the eggs is also relevant, as well as the rightful way in which the powdered eggs manufacturing stages are observed [15], because they could influence the product composition and some of its processing properties [16].

Ultra-high temperature is used during liquid product transformation (atomisation/drying) into the final product - powdered eggs. This also render microbiological sterility to the product $[17,18]$.

The way in each the powder is kept upon usage also affects its inner quality. The main changes are represented by the decreasing of solubility (due to water absorption), lipids oxidation, proteins cleavage, accentuated sensorial alterations etc. [19, 20]. Such changes usually occur when the powdered eggs is keptunder inappropriate conditions (high moisture and temperature environment, differing from the manufacturer recommendations [21, 22].

Another element influencing quality depreciation in powdered eggs is the type of package used as well as the packaging method (under vacuum, using inert gas etc.), aspectalready proven in other type of animal products such as meat based ones [22-24] or dairy ones [25, 26] .

Many research results suggested a negative correlation between package quality/type and microbial contamination level during storage [21-24].

A wide range of materials are available for food packaging, as the subsequent industry is very diversified. The food protection level is given by the used package quality and the selling price varies accordingly [25].

The powdered eggs produced in Romania are marketed (depending on the beneficiary) in bulk packages ( 25 or 50 $\mathrm{kg}$ ) or in small packages ( 0.5 or $1.0 \mathrm{~kg}$ ), bearing a shelf life potential of 12 months if standard storage parameters are provided (temperatures below $+25^{\circ} \mathrm{C}$ ) [8].

Due to the gap of knowledge related to the physical quality of polyethylene bags (permeability for oxygen/water vapours) used in packaging the pow dered eggs under the maximum allowed moisture levels and to the dynamics of

\footnotetext{
* email: dsimeanu@uaiasi.ro
} 
degradations occurring in product after package seal breaking, we aimed to investigate the chemical composition of the pow dered eggs stored under the same environmental conditions and packaged in two different types of polyethylene bags (high density-HDPE and low density-LDPE fabric, respectively).

\section{Experimental part}

Material and method

The investigations were carried on whole powdered eggs (melange - yolks and albumens mixed together) procured from a company producing egg derived commodities. The powder was bought in the very production day, packaged in a $25 \mathrm{~kg}$ paper bag.

Seventy samples have been randomly taken from the initial package, in order to avoid interference with other influential factors than the experimental ones. Each sample weighed $250 \mathrm{~g}$. Half of the samples ( 35 pcs.) were allocated to the control group - Lc - and were packaged in high density polyethylene bags (HDPE), while the other 35 samples were packaged in low density polyethylene bags (LDPE) (experimental group Lexp).

All 70 packages were sealed through thermal suture, then submitted to storage throughout 90 days period, under homogenous microclimate environment (temperature of $10 \pm 0.5^{\circ} \mathrm{C}$ and relative air humidity of $65 \pm 1 \%$ ).

The assessment on the chemical composition traits were carried on several moments, starting from procurement day (day 0 ) and continuing every $15^{\text {th }}$ day till the $90^{\text {th }}$ day. Five bags from each group have been withdrawn from the storage environment in every scheduled inspection moment (10 bags/inspection) and have been unsealed in order to sample powdered eggs to submit it to analytical chemistry tests.

The chemical traits studied during the experiment comprised the water content and the main dry matter fractions (ash, proteins, lipids, nitrogen free extract).

Water content was assessed through oven drying, at $+105^{\circ} \mathrm{C}$ [26], proteins content through the Kjeldahl method [27], lipids content through the Soxhlet method (Velp Scientific-SER 148 device) [28], while the ash content was measured gravimetrically, after samples calcination in furnace at $+550^{\circ} \mathrm{C}$. Dry matter and nitrogen free extract were algebraically calculated based on the other analytical findings [29-38].

The acquired date were processed to obtain the main statistical descriptors (average, variance, standard deviation, standard mean error, variation coefficient), while the significance of the differences between groups mean values was tested using the ANOVA single factor method (Fisher module).

\section{Achieved results}

Water content. The assessments run on fresh pow dered eggs (day 0 ) revealed very close water levels of both groups, i.e. $4.93 \pm 0.03 \%$ in LC and $4.94 \pm 0.03 \%$ in Lexp. The moisture in the analysed product gradually and successively increased, less obvious in the product packaged in high density polyethylene bags-HDPE (LC) and more clear in the one packaged in low density polyethylene bags-LDPE (Lexp) (table 1).

If the inspections run until the $60^{\text {th }}$ day of storage din not revealed statistical significance when the group means were compared, starting from the $75^{\text {th }}$ experimental day, distinguished differences occurred, basing on average

\begin{tabular}{|c|c|c|c|c|}
\hline \multirow{2}{*}{$\begin{array}{l}\text { Storage duration } \\
\text { (days) }\end{array}$} & \multirow{2}{*}{ Group } & \multicolumn{3}{|c|}{ Statistical descriptors } \\
\hline & & $\bar{X} \pm$ & $(\%)$ & $\mathrm{V} \%$ \\
\hline \multirow{3}{*}{0} & Lc & 4.93 & 0.03 & 0.81 \\
\hline & Lexp & 4.9 & 0.03 & 0.60 \\
\hline & \multicolumn{4}{|c|}{ Fisher Test $\hat{F}_{0.02}<$ F5\% (2.99) n.s. } \\
\hline \multirow{3}{*}{15} & $\mathrm{Lc}$ & 4.9 & 0.03 & 3.88 \\
\hline & Lexp & 4.98 & 0.04 & 3.92 \\
\hline & \multicolumn{4}{|c|}{ Fisher Test $\hat{F}_{2.27}<$ F5\% (2.99) n.s. } \\
\hline \multirow{3}{*}{30} & $\mathrm{Lc}$ & 4.9 & 0.04 & 4.96 \\
\hline & Lexp & 5.0 & 0.04 & 4.97 \\
\hline & \multicolumn{4}{|c|}{ Fisher Test $\hat{F}_{2.31}<$ F5\% (2.99) n.s. } \\
\hline \multirow{3}{*}{45} & $\mathrm{Lc}$ & 4.99 & 0.05 & 5.02 \\
\hline & Lexp & 5.09 & 0.05 & 5.09 \\
\hline & \multicolumn{4}{|c|}{ Fisher Test $\hat{F}_{2.45}<\mathrm{F} 5 \%$ (2.99) n.s. } \\
\hline \multirow{3}{*}{60} & Lc & 4.99 & 0.05 & 5.16 \\
\hline & Lexp & 5.1 & 0.06 & 5.20 \\
\hline & \multicolumn{4}{|c|}{ Fisher Test $\hat{F}_{2.71<F 5 \%(2.99)}$ n.s. } \\
\hline \multirow{7}{*}{75} & Lc & 5.03 & 0.06 & 6.05 \\
\hline & Lexp & 5.3 & 0.07 & 6.88 \\
\hline & \multicolumn{4}{|c|}{ Fisher Test $\hat{F}_{5.22}>\mathrm{F} 5 \%(2.99) * *$} \\
\hline & \multirow{4}{*}{ Student Test } & & $\mathrm{Lc}$ & Lexp \\
\hline & & Lexp & 0.32 & 0 \\
\hline & & $\mathrm{Lc}$ & 0 & \\
\hline & & \multicolumn{3}{|c|}{ 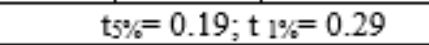 } \\
\hline \multirow{7}{*}{90} & $\mathrm{Lc}$ & 5.0 & 0.08 & 9.06 \\
\hline & Lexp & 5.89 & 0.08 & 15.61 \\
\hline & \multicolumn{4}{|c|}{ Fisher Test $\hat{F}_{18.21}>\mathrm{F} 5 \%(2.99) * * *$} \\
\hline & \multirow{4}{*}{ Student Test } & & Lc & Lexp \\
\hline & & Lexp & 0.83 & 0 \\
\hline & & $\mathrm{Lc}$ & 0 & \\
\hline & & & $=0.30$ & 39 \\
\hline
\end{tabular}

Table 1

DYNAMICS OF WATER CONTENT 
values of $5.03 \pm 0.06 \%$ water in LC group and $5.35 \pm 0.07 \%$ water in Lexp group.

By the end of the experiment ( $90^{\text {th }}$ day of storage), the water content in the analysed product reached an average value of just $5.06 \pm 0.08 \%$ in Lc group, compared to $5.89 \pm 0.08 \%$, measured in Lexp samples; the differences proved to be highly significant.

Variability level indicated better homogeneity in LC samples $(\mathrm{V} \%=0.81-9.06)$, compared to the situation occurred in Lexp group, especially towards the end of storage period $(\mathrm{V} \%=0.60-15.61)$.

Dry matter content. This trait had a decreasing trend, as expected due to the increasing of water level in the product (table 2 ).

In Lc group (high density polyethylene bags-HDPE), the dry matter content reached $95.07 \pm 0.12 \%$ in the fresh product (day 0 ) and $94.94 \pm 0.38 \%$ in that aged 90 days. The studied traithad very good homogeneity in this group, with variation coefficient values of $1.89-9.18 \%$.

In Lexp group (low density polyethylene bags-LDPE), dry matter content reached $95.06 \pm 0.12 \%$ level in the fresh product and $94.11 \pm 0.50 \%$ in that stored 90 days; during the first five inspection we run, the resulted variation coefficient indicated good homogeneity ( $\mathrm{V} \%=2.13$ 7.18), while the two last assessments results indicated $10.10 \%$ and $16.26 \%$ values for the same coefficient, suggesting middle variability.

Distinct significant differences occurred between groups, upon the inspection run in the $75^{\text {th }}$ days of storage and the final one ( $90^{\text {th }}$ day).

Proteins content Constant values were found throughout the experiment in the powdered eggs packaged in high

Table 2

DYNAMICS OF DRY MATTER CONTENT

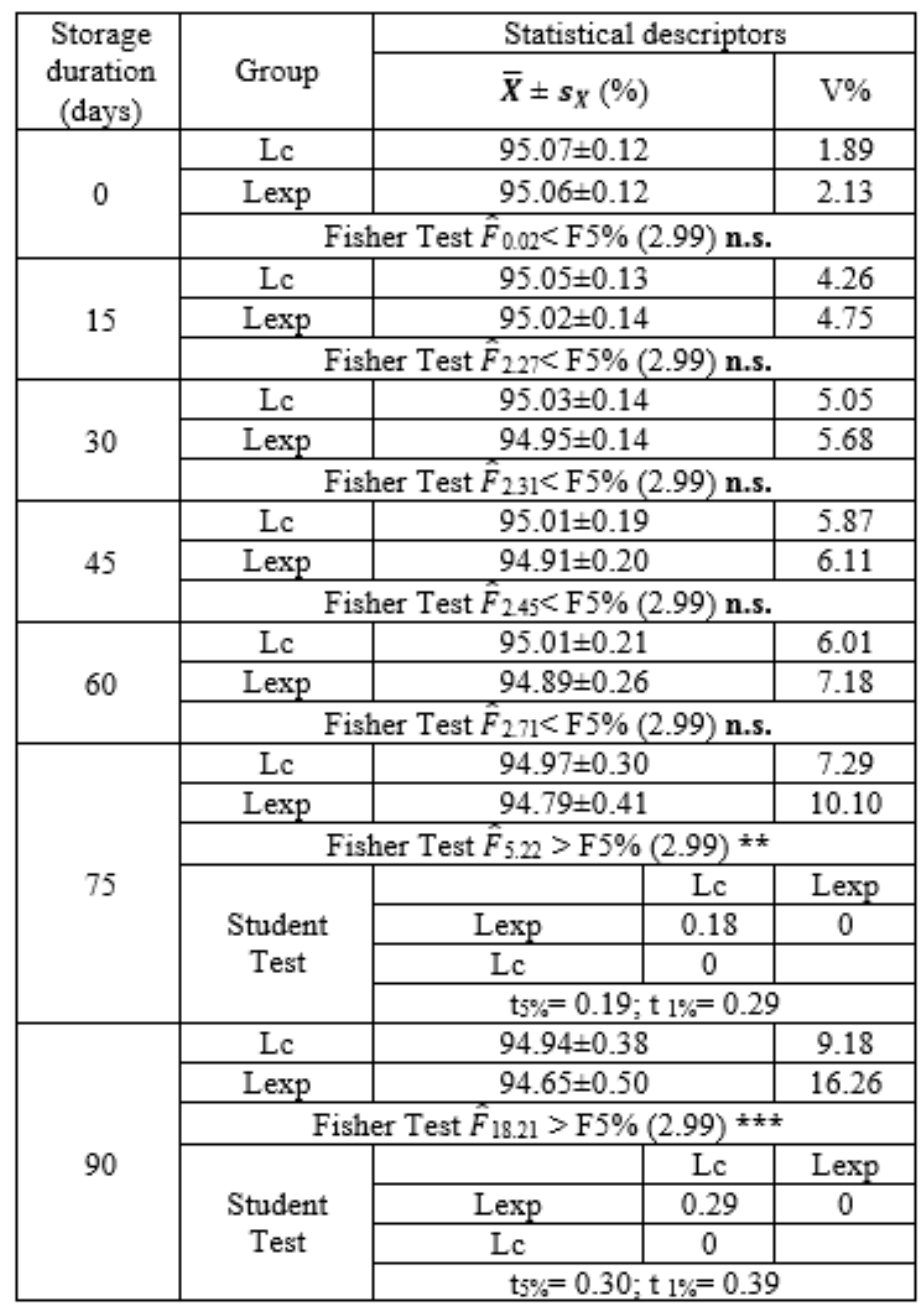

density polyethylene bags-HDPE and slightly decreasing ones in the product packaged in low density polyethylene bags-LDPE. Such lower levels could be explained through protein solubilisation and further decomposition, due to higher water absorption rates from the storage environment (table 3).

Proteins content assessed in the product packaged in high density polyethylene - HDPE (LC group) reached $49.68 \pm 0.08 \%$ in the beginning of the experiment (day 0 ) and $49.65 \pm 0.11 \%$ by its ceasing ( $90^{\text {th }}$ day of storage), while the usage of the low density polyethylene bags-LDPE (Lexp group) to store the product induced initial proteins level of $49.68 \pm 0.10 \%$, and a ultimate percentage of $49.24 \pm 0.13 \%$. statistically significant differences did not occur between groups and experimental moments. The investigated trait was very homogenous, both in Lc group ( $\mathrm{V} \%=3.45-5.29$ ) and Lexp group ( $\mathrm{V} \%=3.12-4.62)$.

Lipids content. This was maintained almost constant, during the entire analysed period (table 4).

Lipids inner content of the fresh product (day 0 ) reached $39.81 \pm 0.04 \%$ in LC group and $39.82 \pm 0.05 \%$ in Lexp group, while in the product aged 90 days (end of the experiment), the lipids levels were quite identical $(39.87 \pm 0.12 \%)$, hence the lack of any statistical significant difference. In both analysed situation, the variation coefficient $(\mathrm{V} \%=1.05-3.17$ in $\mathrm{LC}$ and $\mathrm{V} \%=1.02-2.64 \%$ in Lexp) indicated a very good homogeneity of the trait.

Ash content. Following a similar trend, the minerals content was also quite stable, therefore the assessed levels were no influenced by the way in which the product was preserved. The findings revealed levels of $1.11 \pm 0.01 \%$ crude ash in LC group and of $1.12 \pm 0.01 \%$ in Lexp for the fresh product, while an average percentage of $1.15 \pm 0.04 \%$ resulted for the samples stored 90 days. The homogeneity
Table 3

DYNAMICS OF PROTEIN CONTENT

\begin{tabular}{|c|c|c|c|}
\hline \multirow{2}{*}{$\begin{array}{l}\text { Storage } \\
\text { duration } \\
\text { (days) }\end{array}$} & \multirow{2}{*}{ Group } & \multicolumn{2}{|c|}{ Statistical descriptors } \\
\hline & & $\bar{X} \pm s_{X}(\%)$ & $\mathrm{V} \%$ \\
\hline \multirow{3}{*}{0} & Lc & $49.68 \pm 0.08$ & 3.45 \\
\hline & Lexp & $49.68 \pm 0.10$ & 3.12 \\
\hline & \multicolumn{3}{|c|}{ Fisher Test $\hat{F}_{0.01}<\mathrm{F} 5 \%(2.99)$ n.s. } \\
\hline \multirow{3}{*}{15} & $\mathrm{Lc}$ & $49.68 \pm 0.09$ & 3.97 \\
\hline & Lexp & $49.64 \pm 0.10$ & 3.33 \\
\hline & \multicolumn{3}{|c|}{ Fisher Test $\hat{F}_{0.04<\mathrm{F} 5 \%(2.99) \text { n.s. }}$} \\
\hline \multirow{3}{*}{30} & Lc & $49.67 \pm 0.09$ & 4.15 \\
\hline & Lexp & $49.58 \pm 0.10$ & 3.68 \\
\hline & \multicolumn{3}{|c|}{ Fisher Test $\hat{F}_{0.20}<\mathrm{F} 5 \%(2.99)$ n.s. } \\
\hline \multirow{3}{*}{45} & $\mathrm{Lc}$ & $49.67 \pm 0.10$ & 4.56 \\
\hline & Lexp & $49.55 \pm 0.10$ & 3.90 \\
\hline & \multicolumn{3}{|c|}{ Fisher Test $\hat{F}_{0.51<\mathrm{F} 5 \%(2.99) \text { n.s. }}$} \\
\hline \multirow{3}{*}{60} & Lc & $49.66 \pm 0.10$ & 4.81 \\
\hline & Lexp & $49.42 \pm 0.11$ & 3.97 \\
\hline & \multicolumn{3}{|c|}{ Fisher Test $\hat{F}_{0.90<\mathrm{F} 5 \%(2.99) \text { n.s. }}$} \\
\hline \multirow{3}{*}{75} & Lc & $49.66 \pm 0.11$ & 5.01 \\
\hline & Lexp & $49.38 \pm 0.12$ & 4.13 \\
\hline & \multicolumn{3}{|c|}{ Fisher Test $\hat{F}_{2.12}<$ F $5 \%(2.99)$ n.s. } \\
\hline \multirow{3}{*}{90} & Lc & $49.65 \pm 0.11$ & 5.29 \\
\hline & Lexp & $49.24 \pm 0.13$ & 4.62 \\
\hline & \multicolumn{3}{|c|}{ Fisher Test $\hat{F}_{2.56}<\mathrm{F} 5 \%(2.99)$ n.s. } \\
\hline
\end{tabular}


Table 4

DYNAMICS OF LIPIDS CONTENT

\begin{tabular}{|c|c|c|c|}
\hline \multirow{2}{*}{$\begin{array}{c}\text { Storage } \\
\text { duration (days) }\end{array}$} & \multirow{2}{*}{ Group } & \multicolumn{2}{|c|}{ Statistical descriptors } \\
\hline & & $\bar{X} \pm s_{X}(\%)$ & $\mathrm{V} \%$ \\
\hline \multirow{3}{*}{0} & $\mathrm{Lc}$ & $39.81 \pm 0.04$ & 1.05 \\
\hline & Lexp & $39.82 \pm 0.05$ & 1.02 \\
\hline & \multicolumn{3}{|c|}{ Fisher Test $\hat{F}_{0,02}<\mathrm{F} 5 \%$ (2.99) n.s } \\
\hline \multirow{3}{*}{15} & Lc & $39.82 \pm 0.06$ & 1.38 \\
\hline & Lexp & $39.82 \pm 0.06$ & 1.30 \\
\hline & \multicolumn{3}{|c|}{ Fisher Test $\hat{F}_{0,01}<$ F5 $\%(2,99)$ n.s. } \\
\hline \multirow{3}{*}{30} & Lc & $39.82 \pm 0.06$ & 2.15 \\
\hline & Lexp & $39.83 \pm 0.07$ & 1.88 \\
\hline & \multicolumn{3}{|c|}{ Fisher Test $\hat{F}_{0,02}<\mathrm{F} 5 \%$ (2.99) n.s } \\
\hline \multirow{3}{*}{45} & Lc & $39.83 \pm 0.07$ & 2.22 \\
\hline & Lexp & $39.83 \pm 0.07$ & 1.90 \\
\hline & \multicolumn{3}{|c|}{ Fisher Test $\hat{F}_{0,01}<$ F5\% (2.99) n.s. } \\
\hline \multirow{3}{*}{60} & Lc & $39.84 \pm 0.10$ & 2.45 \\
\hline & Lexp & $39.85 \pm 0.10$ & 1.98 \\
\hline & \multicolumn{3}{|c|}{ Fisher Test $\hat{F}_{0,03}<\mathrm{F} 5 \%(2,99)$ n.s } \\
\hline \multirow{3}{*}{75} & Lc & $39.85 \pm 0.11$ & 2.69 \\
\hline & Lexp & $39.86 \pm 0.12$ & 2.01 \\
\hline & \multicolumn{3}{|c|}{ Fisher Test $\hat{F}_{0,03}<\mathrm{F} 5 \%(2,99)$ n.s } \\
\hline \multirow{3}{*}{90} & $\mathrm{Lc}$ & $39.87 \pm 0.12$ & 3.17 \\
\hline & Lexp & $39.87 \pm 0.13$ & 2.64 \\
\hline & \multicolumn{3}{|c|}{ Fisher Test $\hat{F}_{0.01}<\mathrm{F} 5 \%(2.99)$ n.s. } \\
\hline
\end{tabular}

was very good, both in Lc group ( $\mathrm{V} \%=0.75-3.58)$, and in Lexp group ( $\mathrm{V} \%=0.62-2.65)$ (table 5 ).

No statistical significance occurred for the comparisons run between the average values of the two groups, obtained during each inspection moment for the analysed trait.
Table 5

DYNAMICS OF ASH CONTENT

\begin{tabular}{|c|c|c|c|}
\hline \multirow{3}{*}{$\begin{array}{c}\text { Storage } \\
\text { duration (days) }\end{array}$} & \multirow{2}{*}{ Group } & \multicolumn{3}{|c|}{ Statistical descriptors } \\
\cline { 2 - 4 } 0 & Lc & $\bar{X} \pm s_{X}(\%)$ & V\% \\
\hline \multirow{3}{*}{15} & Lexp & $1.11 \pm 0.01$ & 0.75 \\
\cline { 2 - 4 } & \multicolumn{2}{|c|}{ Fisher Test $\hat{F}_{0.02}<\mathrm{F} 5 \%(2.99)$ n.s. } \\
\hline \multirow{3}{*}{30} & Lc & $1.12 \pm 0.01$ & 0.93 \\
\cline { 2 - 4 } & Lexp & $1.12 \pm 0.02$ & 0.83 \\
\cline { 2 - 4 } & \multicolumn{3}{|c|}{ Fisher Test $\hat{F}_{0.01}<\mathrm{F} 5 \%(2.99)$ n.s. } \\
\hline \multirow{3}{*}{45} & Lc & $1.12 \pm 0.02$ & 1.15 \\
\cline { 2 - 4 } & Lexp & $1.12 \pm 0.02$ & 0.95 \\
\cline { 2 - 4 } & \multicolumn{3}{|c|}{ Fisher Test $\hat{F}_{0.01}<\mathrm{F} 5 \%(2.99)$ n.s. } \\
\hline \multirow{3}{*}{60} & Lc & $1.13 \pm 0.02$ & 1.58 \\
\cline { 2 - 4 } & Lexp & $1.13 \pm 0.02$ & 1.01 \\
\cline { 2 - 4 } & \multicolumn{3}{|c|}{ Fisher Test $\hat{F}_{0.01}<\mathrm{F} 5 \%(2.99)$ n.s. } \\
\hline \multirow{3}{*}{75} & Lc & $1.14 \pm 0.02$ & 2.13 \\
\cline { 2 - 4 } & Lexp & $1.15 \pm 0.03$ & 1.13 \\
\cline { 2 - 4 } & \multicolumn{3}{|c|}{ Fisher Test $\hat{F}_{0.03}<\mathrm{F} 5 \%(2.99)$ n.s. } \\
\hline \multirow{3}{*}{ Lc } & $1.14 \pm 0.03$ & 2.90 \\
\cline { 2 - 4 } & Lexp & $1.15 \pm 0.03$ & 2.15 \\
\cline { 2 - 4 } & \multicolumn{3}{|c|}{ Fisher Test $\hat{F}_{0.04}<\mathrm{F} 5 \%(2.99)$ n.s. } \\
\hline \multirow{3}{*}{ Lc } & $1.15 \pm 0.04$ & 3.58 \\
\cline { 2 - 4 } 90 & Lexp & $1.15 \pm 0.04$ & 2.65 \\
\cline { 2 - 4 } & \multicolumn{2}{|c|}{ Fisher Test $\hat{F}_{0.01}<\mathrm{F} 5 \%(2.99)$ n.s. } \\
\hline
\end{tabular}

rree nitrogen extract content. Uynamics ot this compound in the dry matter was slightly decreasing throughout the experiment, presenting values between $4.47 \pm 0.20 \%$ (day 0 ) and $4.27 \pm 0.11 \%$ (day 90 ) in LC packaging in high density polyethylene bags-HDPE, as well as between $4.44 \pm 0.24 \%$ (day 0 ) and $3.85 \pm 0.12 \%$ (day a 90-a) in Lexp samples, packaged in low density polyethylene bags -LDPE (table 6).

\begin{tabular}{|c|c|c|c|c|}
\hline \multirow{2}{*}{$\begin{array}{l}\text { Storage duration } \\
\text { (days) }\end{array}$} & \multirow{2}{*}{ Group } & \multicolumn{3}{|c|}{ Statistical descriptors } \\
\hline & & $\bar{X} \pm s$ & $(\%)$ & $\mathrm{V} \%$ \\
\hline \multirow{3}{*}{0} & Lc & $4.47=$ & .20 & 3.58 \\
\hline & Lexp & 4.44 & .24 & 5.86 \\
\hline & \multicolumn{4}{|c|}{ Fisher Test $\hat{F}_{0.52}<$ F5\% (2.99) n.s. } \\
\hline \multirow{3}{*}{15} & Lc & \multicolumn{2}{|c|}{$4.43 \pm 0.19$} & 3.62 \\
\hline & Lexp & \multicolumn{2}{|c|}{$4.44 \pm 0.20$} & 6.56 \\
\hline & \multicolumn{4}{|c|}{ Fisher Test $\hat{F}_{0.0}<$ F5\% (2.99) n.s. } \\
\hline \multirow{3}{*}{30} & $\mathrm{Lc}$ & \multicolumn{2}{|c|}{$4.42 \pm 0.18$} & 3.75 \\
\hline & Lexp & \multicolumn{2}{|c|}{$4.42 \pm 0.18$} & 6.99 \\
\hline & \multicolumn{4}{|c|}{ Fisher Test $\hat{F}_{0.01}<$ F5\% (2.99) n.s. } \\
\hline \multirow{3}{*}{45} & Lc & \multicolumn{2}{|c|}{$4.38 \pm 0.16$} & 3.98 \\
\hline & Lexp & \multicolumn{2}{|c|}{$4.40 \pm 0.17$} & 8.12 \\
\hline & \multicolumn{4}{|c|}{ Fisher Test $\hat{F}_{0.35}<$ F5\% (2.99) n.s. } \\
\hline \multirow{3}{*}{60} & Lc & \multicolumn{2}{|c|}{$4.37 \pm 0.15$} & 4.56 \\
\hline & Lexp & \multicolumn{2}{|c|}{$4.37 \pm 0.15$} & 10.25 \\
\hline & \multicolumn{4}{|c|}{ Fisher Test $\hat{F}_{0.02}<$ F5\% (2.99) n.s. } \\
\hline \multirow{3}{*}{75} & Lc & \multicolumn{2}{|c|}{$4.32 \pm 0.13$} & 6.17 \\
\hline & Lexp & \multicolumn{2}{|c|}{$4.26 \pm 0.14$} & 11.72 \\
\hline & \multicolumn{4}{|c|}{ Fisher Test $\hat{F}_{2.69}<$ F5\% (2.99) n.s. } \\
\hline \multirow{7}{*}{90} & Lc & \multicolumn{2}{|c|}{$4.27 \pm 0.11$} & 8.01 \\
\hline & Lexp & \multicolumn{2}{|c|}{$3.85 \pm 0.12$} & 14.21 \\
\hline & \multicolumn{4}{|c|}{ Fisher Test $\hat{F}_{5.21}>$ F5\% (2.99) *ᄎ } \\
\hline & \multirow{4}{*}{ Student Test } & groups & Lc & Lexp \\
\hline & & Lexp & 0.42 & 0 \\
\hline & & $\mathrm{Lc}$ & 0 & \\
\hline & & \multicolumn{3}{|c|}{$\mathrm{t}_{5} \%=0.30 ; \mathrm{t} 1 \%=0.39$} \\
\hline
\end{tabular}

Table 6

DYNAMICS OF THE NITROGEN FREE EXTRACT CONTENT 
The studied trait was highly homogenous in LC $(\mathrm{V} \%=3.58-8.01)$ and less homogenous in the group using packaging in lower quality polyethylene bags $(\mathrm{V} \%=5.86$ 14.21).

\section{Conclusions}

Studying the way in which and the package type influences the egg powder proximate chemical composition throughout the storage led to certain conclusions:

- water content slightly increased throughout storage, due to the different moisture permeability of the package material $(+0.13 \%$ in HDPE-Lc bags, compared to $+0.95 \%$ in LDPE-Lexp bags); consequently, the dry matter content decreased accordingly, as the water one modified;

- although not significant differences occurred for proteins content, in LDPE (Lexp) bags samples, the level quantitatively decreased, due to protein decomposition under the influence of water excess;

- lipids level maintained constant throughout storage (levels of $39.81-39.87 \%$ in Lc group and of $39.82-39.87 \%$ in Lexp group), as well as the crude ash level (1.11-1.15\% in Lc and 1.12-1.15\% in Lexp), which proves the good stability of these two compounds, throughout storage;

- the nitrogen free extract level decreased with $0.20 \%$ (LC group - high density polyethylene) and with 0.59\%, respectively (Lexp group - low density polyethylene) by the end of the experiment, compared to its onset.

Therefore, the type of packaging used for powdered eggs preservation influences its chemical composition, even if the storage is carried on within the parameters recommended by the producer. It is for sure that the chemical modifications of a product presenting high wettability will influence its inner functional and technological traits, with consequences on the food industry/gastronomic usage.

Under such circumstances, we elaborated certain recommendations for the manufacturers, as well as for the end users:

- the powdered eggs should be packaged in high density polyethylene (HDPE) bags, hence they provide the best protection during long term storage (90 days);

- microclimate parameters during HDPE bags storage: max. $+10^{\circ} \mathrm{C}$ temperature and max. $65 \%$ relative humidity;

- low density polyethylene (LDPE) bags could be used if the shelf life of the powdered eggs is intended to reach up to 60 days, within the same microclimate limits (max. $+10^{\circ} \mathrm{C}$ temperature and $\max .65 \%$ relative humidity);

- the whole powdered eggs must be used within 10 days after the package seal is opened.

\section{References}

1.VAARST, M., STEENFELDT, S. HORSTED, K., Sustainable development perspectives of poultry production, World's poultry science journal, 71, no. 4, 2015, pp. 609-620.

2.MARSH, K., BUGUSU, B., Food packaging Roles, materials, and environmental issues, J. Food Sci., vol. 72, 2007, pp. R39-R55.

3.ANTON, M., NAU, F., LECHEVALIER, V., GUERIN-DUBIARD, C., CROGUENNEC, T., Les ovoproduits: des ingredients fonctionnels pour des matrices complexes, INRA Productions Animales, 23, no. 2, 2010, pp. 193-203.

4.HOTCHKISS, J.J., Food-packaging interactions influencing quality and safety, Food Addit Contam vol. 14, no. 6-7, 1997, pp. 601-607. 5.WINDHORST, H.W., Changes in poultry production and trade worldwide, World's poultry science journal, 62, no. 4, 2006, pp. 585602.

6.BARON, F., JAN, S., Microbiologie de l'oeuf et des ovoproduits, INRA Productions Animales, vol. 23, no. 2, 2010, pp. 215-224.
7.ARAGON-ALEGRO, L.C., SOUZA, K.L.O., SOBRINHO, P.S.C., LANDGRAF, M., DESTRO M.T., Avaliação da qualidade microbiológica de ovo integral pasteurizado produzido com e sem a etapa de lavagem no processamento (Influence of washing in the microbial quality of pasteurized egg), Ciênc. Tecnol. Aliment, vol. 25, 2005, pp.618-622. 8.GUILMINEAU, F., KULOZIK, V., Influence of thermal treatment on the functionality of hens egg yolk in mayonnaise, Journal Food Eng., 78, 2007, pp 648-654.

9.SURAI, P.F., SPARKS, N.H.C., Designer eggs: from improvement of egg composition to functional food, Trends in Food Science and Technology, 12, 2001, pp. 7-16.

10.TALANSIER E., LOISEL C., DELLAVALLE D., DESRUMAUX A., LECHEVALIER V. AND LEGRAND D., How optimising dry heattreatments of egg white pow ders regarding foam and interfacial film properties, Lebensmittel wissenschaft and tehnologie, 42, 2009, pp. 496-503.

11.RATU, R.N., USTUROI, M.G., Physical-chemical evaluation of liquid products from pasteurized eggs University of Agricultural Sciences and Veterinary Medicine Iasi, Lucrari Stiintifice - Seria Zootehnie, 64, no. 20, 2015, pp. 104 - 109.

12.USTUROI, M.G., Producerea oualor de consum. Editura Ion Ionescu de la Brad, lasi. 2004, p. 209.

13.HASLER, C.M., The changing face of functional foods, Journal of the American College of Nutrition, Vol. 19, 2000, pp. 499S-506S.

14.LAI, C.C., GILBERT, S.G., MANNHEIM, C.H., Effect of composition on the flow properties of egg powders, J ournal Food Science, 50, no. 6, 1985, pp. 1618-1620.

15.LECHEVALIER, V., JANTET, R., ARHALIASS, A., LEGRAD, J ., NAU, F., Egg white drying: influence of industrial processing steps on protein structure and functionalities, Journal Food Eng., 83, no. 3, 2007, pp. 404-413.

16.ANTON, M., GANDEMER, G., Composition, solubility and emulsifying properties of granules and plasma of egg yolk, Journal Food Science, 62, no 3, 1997, pp. 484-487.

17.NYS, Y., BAIN, MAUREEN, VAN IMMERSEEL, F., Improving the safety and quality of egg and egg products, Woodhean Publishing Limited, Cambridge, UK, 2011.

18.J ONES, D.R., MUSGROVE, M.T., Effect of extended storage on egg quality factors', Poultry Science, vol. 84, 2005, pp. 1774-1777.

19.ACTON, J.C., KARTIKA, S., BOUSTER, A., DAWSON, P.L., Packaging systems: Effects on poultry product color and other quality factors, XII European Poultry Conference Verona-Italy, Book of Abstracts, 2006, p. 14.

20.RATU, R.N., USTUROI, M.G., ALBU, A., Quality of powder egg stored in different conditions, Lucrari Stiintifice, Seria Zootehnie, Ed. Ion Ionescu de la Brad, Iasi. 63, no. 20, 2015, p. 122.

21.MIKOVA, K., BOSKOVA, H., The influence of storages temperature on egg white proteins, $X I I^{\text {th }}$ European Poultry Conferance, ToursFrance, Book of abstracts, 2010, p. 154.

22.AHN, D., KIM, S., SHU, H., Effect of egg size and strain and age of hens on the solids content of chicken eggs, Poultry Science, vol. 76, no. 6, 1997, pp. 914-919.

23.ACTON, J.C., STEPHENS, C., SHAVER, V.A., DAWSON, P.L., Packaging of fresh meat and meat products, XVIII European Symposium on the Quality of Poultry Meat, Prague, 2007, pp. 142-146.

24.J AYASINGH, P., CORNFORTH, D.P., BRENNAND, C.P., CARPENTER, C.E., WHITTIER, D.R., Sensory evaluation of ground beef stored in high-oxygen modified atmosphere packaging, J ournal of Food Science, 67, no. 9, 2002. pp. 3493-3496.

25.SEYDIM, A.C., ACTON, J.C., HALL, M.A., DAW SON, P.L., Effects of packaging atmospheres on shelf-life quality of ground ostrich meat, Meat Science, 73, 2006, pp. 503-510.

26.GAIANI, C., SCHUCK, P., SCHER, J., HARDY, J., DESOBRY, S., BANON, S., Dairy powder rehydration: influence of protein state, incorporation mode and agglomeration, Journal Dairy Science, 90, 2007, pp. 570581.

27.GAVRIL, R.N., USTUROI, M.G., Contributions to the knowledge of qualitative parameters for egg powder, The $13^{\text {th }}$ International 
Symposium: Prospects for the 3rd Millennium Agriculture, Bulletin UASVM Food Science and Technology, 71, no. 2, 2014, pp. 179 - 187. 28.ORKUSZ, A., WO $O O S Z Y N$, J., OKRUSZEK, A., Influence of packaging materials on microbiological quality and odour of turkey thigh muscles packaged under modified atmosphere, Arch.Geflügelk. Verlag Eugen Ulmer, Stuttgart, 76, no. 3, pp. 208-213.

29.MILUTINOVIC, M., HADZISTEVIC, M., MOVRIN, D., VRBA, I., Non conventional Methods for Shaping Plastics Parts, Mat. Plast., 48, no. 3, 2011, p. 222

30.PIRINGER, O.G., Prediction of Diffusion Coefficients in Plastic Materials, Rev. Chim. (Bucharest), 59, no. 11, 2008, p. 1186 31.FILIMON, V., BORDA, D., ALEXE, P., STOICA, M., Study of PATP Impact on Food Packaging Materials, Mat. Plast., 53, no. 1, 2016,p. 48 32.DAWSON, P.L., STEPHENS, C., Poultry packaging-Poultry Meat Processing and Quality, Woodhead Publishing Limited, Cambridge, England, 2004, pp. 135-163.

33.ASSOCIATION OF OFFICIAL ANALYTICAL CHEMISTS - AOAC, Official Methods of Analysis 15th Edition, Volume Two - Food Compositions; Additives; Natural Contaminants, edited by Kenneth Helrich, Published by the Association of Official Analytical Chemists, Inc., Arlington, Virginia. Solids (total) in eggs - 925.30, 1990, p. 851
34.*** ASSOCIATION OF OFFICIAL ANALYTICAL CHEMISTS - AOAC, Official Methods of Analysis 15th Edition, Volume Two - Food Compositions; Additives; Natural Contaminants, edited by Kenneth Helrich, Published by the Association of Official Analytical Chemists, Inc., Arlington, Virginia. Nitrogen in eggs Kjeldahl Method - 925.31, 1990, p. 854

35.*** ASSOCIATION OF OFFICIAL ANALYTICAL CHEMISTS - AOAC, Official Methods of Analysis 15th Edition, Volume Two - Food Compositions; Additives; Natural Contaminants, edited by Kenneth Helrich, Published by the Association of Official Analytical Chemists, Inc.,Arlington, Virginia. Fat in eggs Acid hydrolysis method 925.32, 1990, p. 854

36.BIRGHILA, S., BRATU, M.M., PRAJITURA, C., RONCEA, F.N., NEGREANU-PIRJOL, T., Spectrophotometric Method for the Determination of Total Proteins in Egg White Samples. Rev. Chim. (Bucharest), 66, no. 3, 2015, pp. 378-381.

37.BERARDINELLI, A., RAGNI, L., CEVOLI, C., SILAGHI, F., SIRRI, F., MELUZZI, A., Assessment of yolk/albumen ratio in whole liquid egg products by time-domain reflectometry (TDR) method, XIII ${ }^{\text {th }}$ European Poultry Conference, Tours-France. Book of Abstracts, 2010, p. 177. 38.SAUVEUR, B., Metode d'elevage des poules et qualite de l'oeuf de consummation. INRA Prod. Anim., no. 4, pp. 123 - 130.

Manuscript received: 21.12 .2016 